\title{
Strapped for Cash? Funding for UK High Growth SMEs since the Global
}

\section{Financial Crisis}

\begin{abstract}
While high growth firms (HGFs) are crucial drivers of economic growth, to date there has been a dearth of research examining their funding requirements. Drawing on a survey of over 8,000 UK Small and Medium Sized Enterprises (SMEs), this paper investigates the capital structure and access to credit in high growth SMEs in the period following the global financial crisis. The findings challenge conventional wisdom about high growth SMEs in certain respects. They find it no harder than non-high growth SMEs to access external finance. The vast majority of high growth SMEs rely strongly on debt-based finance for their funding, not equity finance. High growth SMEs are much less likely to seek finance for working capital purposes but are no more likely to seek finance to invest in R\&D than less rapidly growing SMEs. The findings suggest little justification for government intervention aimed at increasing credit availability for HGFs as currently espoused by the UK government.
\end{abstract}

Keywords: Entrepreneurship; SMEs; Gazelles; Innovation; Access to finance; Policy JEL Codes: O31, G21, G32, L26 


\section{Introduction}

This paper investigates the capital structure and access to credit in UK high growth small and medium-sized enterprises (SMEs) in the period following the global financial crisis. Firms achieving rapid growth in employment or turnover are vital for innovation and economic growth (Shane, 2010; Mason and Brown, 2013). Research interest in so-called high growth firms (HGFs) stems from the pioneering work by David Birch (1981). From a policy perspective the key attraction of these firms is unquestionably their prodigious ability to generate 'jobs'. Consequently, organisations like the US Small Business Administration, the EU, World Bank and OECD have all been instrumental in propagating the importance of these dynamic small firms within enterprise policy frameworks (Brown et al, 2017; McKenzie, 2017; Welter et al, 2018).

While the literature examining the traits and characteristics of HGFs has expanded considerably in recent years (Henrekson and Johansson, 2010; Demir et al, 2017), research has largely overlooked their growth obstacles (Lee, 2014). Finance is an important enabler of rapid firm growth in SMEs (Dobbs and Hamilton, 2007), allowing firms to invest in physical and human capital, develop new products/processes and reach new markets. However, the growth process is likely to strain firm balance sheets, as firms require capital for new staff, new product development or inventory. For multiple reasons, therefore, access to finance may be a particularly pressing issue for high growth SMEs. Despite the importance of financial issues for SMEs to grow rapidly, research examining this issue has been "surprisingly scant" (Demir et al, 2017, p. 453). Examining these financial constraints is pivotal for understanding the growth determinants of HGFs. 
These issues also have strong policy resonance. Increasing access to credit for SMEs is a core policy objective and according to the UK government accessing finance is a "disproportionately important obstacle" for HGFs (BIS, 2012, p.7). High growth ventures are often strongly equated with equity finance (see Duruflé et al, 2017) which is considered "particularly suitable for growing businesses" to enable them to "scale-up up" (British Business Bank 2016, p. 56). However, to date there is very little recent concrete evidence to suggest these firms are either "strapped for cash" and/or rely on equity sources of finance.

To examine this issue, the paper investigates the factors underpinning the applications for finance made by rapidly growing SMEs; the types of finance they apply for; the reasons for applications and the success of these applications. The paper draws on cross-sectional UK data to compare how high growth SMEs compare to less rapidly growing SMEs. We draw on a major survey of over 8,000 UK SMEs surveyed during $2007 / 8,2010$ and 2012 and use a combination of descriptive statistics and regression models. The data was collected in the immediate aftermath of the global financial crisis (GFC) when bank lending collapsed ${ }^{1}$. While there is strong evidence how the GFC impacted UK SMEs as a whole (Cowling et al, 2012; Lee et al, 2015), no studies have specifically examined how this particularly affected access to finance in high growth SMEs.

Our results strongly suggest HGFs find it no harder than other firms to access external finance. Therefore, the findings refute the "strapped for cash" thesis embedded in UK policy frameworks and suggest little justification for targeted government intervention specifically aimed at increasing credit availability for HGFs. If enterprise

\footnotetext{
${ }^{1}$ Ivashina and Scharfstein (2010) note that new loans to borrowers fell by $47 \%$ during the peak period of the financial crisis during the fourth quarter of 2008. Furthermore, Cowling et al (2012) highlight that six months into the crisis nearly $10 \%$ of UK SMEs were denied access to finance.
} 
policies are to be effective and evidence-based it is important that the relevant actors are informed about the financial landscape facing high growth SMEs (Wright et al, 2015).

The paper is structured as follows. Section two examines relevant literature and hypotheses. It then outlines the data and descriptive statistics. Section four outlines the regression models testing whether HGFs are more or less likely to successfully access finance. The penultimate section discusses implications of the work, it then concludes with future research suggestions.

\section{Literature Review}

\subsection{Theoretical Background}

Information asymmetries are viewed as the main theoretical premise for the difficulties SMEs face when accessing external finance (Petersen and Rajan, 1994). In their seminal article, Stiglitz and Weiss outline why imperfect information makes it difficult to differentiate between "bad" and "good" borrowers (1981, p. 393). In a world of perfect and costless information, a bank would stipulate all the actions a borrower needs to enact to ensure repayment of a loan. However, given these pre-conditions are unfeasible, in equilibrium, a loan market may be characterised by loan rationing (Stiglitz and Weiss, 1981).

A core problem facing start-ups and SMEs accessing finance is their informational opacity (Berger and Udell, 1998; Cassar, 2004). Owing to this, SMEs are often required to issue loan security but are often denied finance owing to their lack of collateral (Berger and Udell, 1998; Comeig et al, 2015). Scholars have also noted the increasing tendency by banks to use transactional lending practices using quantitative credit scoring 'data' rather than relational banking connections further increases the informational friction between small business borrowers and lenders (Berger \& Black, forthcoming; Udell, 2015). The rapid onset of "Fintech" is further promoting a reliance on sophisticated proprietary credit-scoring 
techniques (Frame et al, 2018) such as digital footprinting for assessing the likelihood of debt defaults (Berg et al, 2018). Owing to these factors, the notion that that smaller firms face credit rationing has become deeply entrenched in the literature and policy sphere (Cressy, 2002), despite mixed supporting evidence (Vos et al, 2007).

\subsection{Hypothesis Development}

Turning to the specific issue of financing for HGFs, prior studies typically suggest that internal finance is often insufficient to finance rapid growth (Michaelas et al, 1999) as most "have considerable outside financing needs" (Vanacker and Manigart, 2010, p. 54). High growth SMEs are particularly likely to be innovative (Segarra and Ternel, 2014) and innovative assets can be hard to value which may lead to problems for SMEs accessing finance (Lee and Brown, 2017). Indeed, the bulk of prior empirical evidence suggests that HGFs find accessing finance more problematic than other non-HGFs (see Table 1 below for a summary of empirical studies). However, many of these studies occurred in the $1980 \mathrm{~s} / 90 \mathrm{~s}$ prior to the recent GFC. Indeed, credit constraints may have worsened since the GFC, as funding institutions increasingly re-oriented credit to larger firms, irrespective of their growth ambitions (Cowling et al. 2012). This leads to our first set of hypotheses:

Hypothesis 1 High-growth SMEs are more likely to seek external sources of funding than less rapidly growing SMEs

Hypothesis 2 High-growth SMEs find it more difficult to obtain external funding than non HG SMES

Insert Table 1 here around here

The literature on access to funding within SMEs often ignores the reasons why firms seek access to external sources of credit despite the fact this can have important implications for 'valuing risk'. Clearly, firms experiencing periods of very rapid growth will 
require funding for different purposes to less rapidly growing firms. Slower growing companies may need finance to aid cashflow and/or to fund their day-to-day activities. Conversely, it would be expected that growth-inducing investments, like research and development (R\&D) and acquisitions, would be more likely for high growth SMEs. The corollary of this is that less rapidly growing firms are more likely to be risk averse, perhaps using funding to invest in assets with guaranteed resale value such as property of plant and equipment. This leads us to the following set of hypotheses:

Hypothesis 3 High-growth SMEs are less likely to use external funding to fund working capital than non HG SMEs

Hypothesis 4 High-growth SMEs use funding for riskier strategic investments such as R\&D than non-high growth SMEs

Under the 'pecking order' theory (Myers and Majluf, 1984), firms are predicted to have a pecking order of funding preferences. In line with this hypothesis, firms are expected to first seek $i$ ) financing from internal sources of finance ii) debt funding and iii) equity sources of finance as a last resort. We would expect high growth SMEs would wish to maintain outright ownership of their respective ventures so in accordance with the "pecking order hypothesis' we posit the following final hypothesis:

Hypothesis 5 High growth SMEs will seek non-equity dilutive sources of funding

\section{Data and Definitional Issues}

\subsection{Data}

The data for this study is the combined Small Business Survey (SBS) for 2007/8, 2010 and 2012. ${ }^{2}$ All firms surveyed are SMEs with less than 250 employees, as defined by the

\footnotetext{
${ }^{2}$ Note that in $2007 / 8$ this survey was called the Annual Small Business Survey.
} 
European Union ${ }^{3}$. The SBS is a repeat cross-sectional survey commissioned by the UK government and conducted via Computer Assisted Telephone Interview. The questions were asked of owners or senior decision makers in each firm. SMEs are selected using a stratified sample, with quotas for nation/region, size and sector. Within this, firms are randomly selected from the Dun \& Bradsteet database. The survey includes firms across the UK, although weights are used in the analysis to account for oversampling of some regions or nations.

For the purposes of this study two sets of firms were removed from the data. First, as is standard in the literature on HGFs, firms with less than 10 employees in the initial year of analysis are excluded. Including very small firms in the measure would bias the interpretation of high growth, as it is easier for a small firm to achieve rapid growth than one which starts larger (for example, a sole trader taking on a single employee would be counted as having doubled in size although the absolute increase is minimal). Second, firms with missing values for the variables used are excluded. ${ }^{4}$ This is largely a random process as some firms are only asked a sub-set of questions in each year. This resulted in a total sample of 8,830 firms, of which 4,060 were sampled in 2007/8, 2,145 in 2010 and 2,625 in 2012 (see Table 2 below).

Insert Table 2 around here

\subsection{Identifying high growth firms}

There are debates in the literature on high growth firms about whether to use a turnover or employment measure of high growth (Daunfeldt et al, 2015). However, the SBS

\footnotetext{
${ }^{3}$ https://ec.europa.eu/growth/smes/business-friendly-environment/sme-definition_en

${ }^{4}$ We drop only 291 observations.
} 
only includes actual data on past employment (although it does ask whether turnover has increased). Therefore, employment growth is used as a core measure of firm growth. A methodological challenge for the paper is when to investigate the financing decisions of HGFs. Success in accessing finance may be endogenous with the ability to achieve high growth, as firms which do not obtain finance may not be able to achieve growth as a result. So we choose to consider firms who have achieved some growth and believe they will be able to sustain it. In line with other research using this dataset (Lee, 2014), high growth SMEs are defined as those which have grown at $20 \%$ or more for one year and which predict $20 \%$ or more within the next. Of course the desire to grow is not the same as having the ability to grow. As an additional check, firms which say that they have not achieved 'growth' in a further question are excluded. While this is not a perfect measure of firm growth it does correlate strongly with actual firm growth measures. ${ }^{5}$

This strength of this method is that it avoids the conceptual problem that firms which do not achieve external finance may not then be able to grow, yet there are two important considerations. First, firms may not be able to reliably predict future growth. This may lead to a bias either towards optimistic firms, who are more likely to be seen as high growth, and away from pessimistic firms which are less likely to be seen as high growth. A second problem is that by only using a two year time period, rather than the three year period used in other recent UK studies ${ }^{6}$, this may overestimate the share of firms which achieve high growth relative to other work. However, the advantage of this method is that it

\footnotetext{
${ }^{5}$ The 2010 wave can be linked into the Business Structure Database which gives actual employment growth over the subsequent year. Using this method to test the robustness of firm predictions shows a strong and positive correlation between expected growth and actual growth of $0.8(p=0.0000)$. While these predictions will be wrong for a minority of firms, the majority of firms seem able to predict employment growth over the forthcoming year with some degree of accuracy.

${ }^{6}$ There are however significant variations in the definitions used to define high growth (see Henrekson and Johansson, 2010).
} 
captures firms who are undergoing a spell of rapid growth, rather than those who have exited it. Plus, analysis of the same factors using other data suggests the main results are robust using alternative definitions. ${ }^{7}$

Table 2 shows the share of HGFs in the sample using this method. Of the full sample, just fewer than 5 percent are high growth SMEs (4.7\%). More firms were high growth before the financial crisis in 2007/8 (5.4\%), than immediately after in 2010 (3.6\%) or in 2012 (4.5\%). However, there was a significant uplift between 2010 and 2012. These figures are slightly below other estimates for the earlier periods: some scholars estimate six percent of firms achieved high growth (Anyadike-Danes et al. 2009). This provides some evidence to suggest the results of this project are not unduly affected by optimism bias. Note that the results of this project differ from other studies as this project only considers SMEs, whereas others considered all firms with ten-plus employees (Anyadike-Danes et al. 2009).

\section{Descriptive statistics: Financing high growth firms}

\section{Applications for finance and rejection rates}

Following Lee et al. (2015), a number of variables on access to finance are constructed. First, applications for finance: HGFs are significantly more likely to apply for finance than other firms (see Table 3 below). Exactly a third of all firms in the survey had applied for finance in the previous 12 months. But $44 \%$ of high growth firms applied. We use a weighted t-test to assess how reliable this finding is and it is statistically significant $(p<0.000)$. This provides strong evidence in support of hypothesis 1 , that HGFs will be more likely to seek external finance.

\footnotetext{
${ }^{7}$ It is possible to investigate the results here using a smaller sample of 1,300 firms linked into administrative data on turnover growth. The results suggest that neither use of turnover rather than employment nor our mid-growth definition of HGFs alters the main results. Results are available on request.
} 
Table 3 around here

Next, we consider rejection rates and the extent to which HGFs were refused funding. We consider two potential results: having difficulty obtaining finance from the first source, and being unable to get any finance from any subsequent source. Hypothesis 2 suggests that HGFs will find it harder to access finance than other firms. Yet the results here suggest HGFs have no more, or less, of a problem accessing finance than other firms: $34 \%$ of firms who applied for finance had trouble, with $32 \%$ of HGFs. The latter were slightly less likely to fail to get any finance from any source ( $13 \%$ compared to an average of $16 \%$ for non-HGFs). None of these differences are statistically significant. Regardless, this provides cause to reject hypothesis 2 .

\section{Sources of finance for high growth firms}

An important consideration is whether HGFs are more likely to fund their growth through internal resources, such as retained earnings, rather than through external sources of finance (see Table 4 below). In the SBS, firms which aimed to grow were asked whether they would fund this expansion using internal or external finance in both the $2007 / 8$ and 2010 surveys. This information is used to assess whether HGFs are more likely to seek to fund growth using internal resources, although for a smaller sample.

\section{Table 4 around here}

The results show that HGFs are particularly likely to fund expansion using a combination of both internal and external finance: $34 \%$ of them would do this, compared to 24 percent of other firms. This shows that HGFs are more inclined to use a 'cocktail' approach to funding, involving both retained and external sources of finance. In contrast, HGFs are less likely to only use internal finance (only $51 \%$ of firms compared to $61 \%$ of others). 
Note, however, that HGFs are more likely than other firms to apply for finance. To test if this affects the results, we also include the share accessing each type of finance from the share of all firms, regardless of whether they apply for finance (given in parenthesis). When considering all firms, HGFs are particularly likely to finance growth using all three measures. The largest gap, however, is that HGFs seem particularly able to look to finance growth through both internal and external resources: $10 \%$ of all firms look to finance growth in this manner, whereas $20 \%$ of HGFs do. Internal finance is clearly unable to wholly satisfy the strong appetite for external sources of finance within HGFs.

\section{Reasons for applying for finance}

An important secondary consideration is that HGFs may be applying for finance for different reasons to other firms. Hypothesis 3 suggested HGFs would be less likely to use external finance to fund working capital; hypothesis 4 suggested they would use funding for 'riskier' strategic investments than other firms such as R\&D. This may then affect their likelihood of receiving finance. For example, banks may be more willing to lend to a firm to purchase buildings or capital equipment than to lend to one aiming to invest in R\&D owing to the higher 'sunk costs' involved in such activities. The SBS contains data on a number of reasons for accessing finance, although sample sizes are relatively small.

Table 5 presents the results of the breakdown and shows that HGFs differ significantly in their reasons for accessing finance. Indeed, they are significantly less likely to be accessing finance to use as working capital than other firms ( $36 \%$ relative to $47 \%)^{8}$, although a high share are still likely to be doing so. Many HGFs are accessing capital to invest in buildings or equipment. Hypothesis 3 suggested high-growth SMEs were less likely

\footnotetext{
8 "Working capital" is everyday finance used by a firm to pay basic outgoings, rather than finance used for a specific source such as investment.
} 
to use external funding to fund working capital than non-HGFs. We therefore find strong evidence to support hypothesis 3.

\section{Table 5 around here}

Only a small proportion of high growth SMEs apply for finance for R\&D. R\&D spending is dominated by large firms, not SMEs, so this is perhaps unsurprising. Yet we might expect high-growth SMEs to be more likely to be investing in R\&D than other SMEs. One potential explanation is the small sample size. Another is that HGFs may have applied in the past, with the funding application predating rapid growth. An alternative explanation is given by Mason and Brown (2013) who suggest many HGFs use external sources of knowledge from customers and end-users as innovation inputs rather than formal R\&D spending as their main source of innovation.

There is little difference between HGFs and other firms in the share of applications made for buying or improving buildings (19\%) or those acquiring capital equipment or vehicles (26\%). Yet HGFs are more likely to apply for finance for two important growthrelated reasons: to buy another business ( $7 \%$ of HGFs, compared to $2 \%$ overall) and to 'fund expansion' (9\% compared to 3\%). Both these differences are statistically significant. That HGFs are more likely to be buying other businesses suggests that the general perception of the increasing importance of external growth is correct (McKelvie and Wiklund, 2010). These different patterns of growth create demand for a different composition of long and short-term funding which requires further investigation.

Overall, this finds some partial support for Hypothesis 4, that high-growth SME use funding for riskier investments than other firms. HGFs are more likely to use finance to fund expansion and growth through acquisition but no more (or less) likely to seek external finance for R\&D. 


\section{Types of finance sought by high growth firms}

Next, we consider the types of finance firms seek. The SBS asks firms who apply for finance what type of finance they seek, and a number of responses are given (ranging from bank loans to Community Development Finance). However, many of the smaller categories are only asked in single waves and can have very small sample sizes. To prevent this from biasing the results, only seven base categories of finance are considered: bank loans; bank overdrafts; venture capital; grant, leasing and hire purchase; loans from family / business partners / directors, and; mortgages for property purchases / improvements.

As shown in Table 4, the most common type of finance applied for is a bank loan ( $40 \%$ of firms in the sample). Forty nine percent of HGFs applied for bank loans compared to $39 \%$ of other firms (this difference is statistically significant). The second most common form of finance is bank overdrafts, which $26 \%$ of firms apply for. However, in this case HGFs are significantly less likely to apply ( $18 \%$ compared to $27 \%)$. This may reflect the greater reliance on working capital rather than growth finance for non-high growth SMEs.

Hypothesis 5 suggested that HGFs were more likely to seek non-equity dilutive finance. This appears to be supported to some degree, as they are more likely to apply for bank loans than other firms. Yet because a far higher share utilise venture capital than nonHGFs, albeit a small overall proportion $(<5 \%)$, the hypothesis does seem to be contestable up to a point.

\section{Model and estimation strategy}

\section{Empirical Model}

Hypotheses 1 and 2 both considered the extent to which HGFs applied for finance and their likelihood of rejection. To test whether these results are driven by their status as HGFs, or the other characteristics of firms which are likely to achieve high growth, a set of 
probit regression models are estimated. These estimate the likelihood of firms finding it hard to access finance as a function of both high-growth status and other variables such as size, sector and age.

Our methodology develops from contributions such as Fraser (2009) in using simple probit models alongside Heckman selection models to investigate this research question (see also Mina et al. 2013; Lee et al. 2015). The basic model is as follows:

$$
\text { FINANCE }_{i}=\alpha+\beta_{1} \text { GROWTH }_{i}+\beta_{2} \text { FIRM }_{i}+\beta_{3} \text { OWNER }_{i}{ }^{+} \beta_{4} \text { YEAR }_{i}{ }^{+} \phi_{i}+\varepsilon
$$

For firm ' $i$ '. Where 'FINANCE' is one of a series of variables for difficulty in obtaining finance (as outlined in table 2 and 3), $\alpha$ is the constant, 'GROWTH' is whether the firm is undergoing high growth, FIRM is a series of firm level characteristics such as size and age, OWNER is the characteristics and qualifications of the owner or management team, $\phi$ are sectoral controls and $\varepsilon$ is the error term.

The estimation method takes two forms. First, simple probit regression results are estimated. ${ }^{9}$ However, a complication is that certain firms are more likely to apply for finance, and this may be correlated. To address this in a second set of models selection effects are controlled for, and estimate a two-stage heckman probit regression. This requires a variable to be included in the selection equation (which estimates the probability of applying for finance) but not in the basic regression (which estimates likelihood of problems obtaining finance, corrected for the likelihood of applying). Legal status is used as the selection variable.

\section{Control variables}

\footnotetext{
${ }^{9}$ Note we also conduct robustness tests using logit and OLS models with the same specification. These seem to make little difference to the main results. Results available on request.
} 
Other factors may influence the ability of firms to access finance or not. To ensure these are not affecting the link between HGFs and access to finance, the model controls for a series of other potential explanatory variables ${ }^{10}$.

First, the sample of firms spans a 5-year time period which included both major economic change and significant variation in the supply of credit. Bank lending tightened considerably following the financial crisis which began in 2008 (Cowling et al. 2012). To control for this cyclical effect, two binary variables are used which take the number one if a firm is sampled in 2010 or 2012 . The reference category is before the recession (2007/8) and so we expect both variables to be positive.

Size will also be an important determinant of lending decisions (Cowling et al. 2012). Larger firms will often represent safer investments, and size is sometimes used a proxy for risk by banks. Because of this, we expect larger firms to be better able to access finance. The model controls for this using three size dummies, based on total employment in the year before the survey.

Similarly, age will be important for firms. Older firms will have longer-track records and so seem a 'safer bet' for investors. Two dummy variables (which take the value 0 or 1 ) are used to account for this, whether firms are 5-9 years old, or $10+$. The reference category is young firms under five years old, and we expect each dummy variable to be positively related to difficulties accessing finance.

Entrepreneur characteristics and access to credit have been a controversial area of research. Because banks often make decisions based on firm size, age and balance sheets, rather than the characteristics of entrepreneurs, it might be argued that this is unimportant.

\footnotetext{
${ }^{10}$ We control for factors such as size, age and aim to grow. Unfortunately, however, we could not control for levels of collateral due to a lack of appropriate questions in the survey examined.
} 
Research on whether ethnic minorities find it harder to access finance supports this interpretation and finds less impact (Fraser, 2009). Our model controls for three entrepreneur characteristics: whether firms are female-led, ethnicity and whether the entrepreneur has a qualification. We expect positive signs on the first two but, as human capital is important for entrepreneurial success, the latter to have a negative impact. An additional variable for entrepreneurial human capital is the number of directors. Where firms have more directors, and so more experience, contacts and knowledge, they may be better able to access finance. ${ }^{11}$

The growth ambitions of a company may also be important and a variable for whether firms aim to grow is included. Clearly, aiming to grow is likely to be positively related to applications for finance. Firms which aim to grow will, on the one hand, make more ambitious applications, yet they may also have better business plans and/or more attractive financial projections. Because of this, the sign of the coefficient is ambiguous. Seeking advice before applying is also likely to be crucial in helping firms access finance (Rostamkalaei and Freel, 2017). We include a variable for this, which we expect to be negatively related to rejection rates.

Finally, two legal dummies for whether a firm is a partnership or a limited company are included. Past research has shown a link between legal structure and applications for finance, but shows little relationship with the success of applications (Mina et al. 2013). Consequently, this is included in regressions controlling for selection bias as the 'selection variable'

\section{Results}

\footnotetext{
${ }^{11}$ We also consider potential non-linearities in the number of directors using a quadratic term or dummy variables for different sizes. But these suggest that the relationship is linear.
} 
The basic models for access to finance are included in Table $6 .{ }^{12}$ The first set of models $(1-3)$ are estimated as simple probit regressions, without controlling for selection. For ease of interpretation, we present marginal effects. The next (models $4-5$ ) use the standard Heckman correction for selection effects.

\section{Table 6 around here}

Column one gives the results for whether firms apply for finance. They show that HGFs are around 7 percent more likely to apply for finance than other firms, a finding which is statistically significant. This reflects the descriptive statistics presented earlier, which showed no reason to reject the hypothesis that HGFs will be more likely to seek external finance than other firms.

The results also suggest other drivers of finance applications. As expected, firms which aim to grow are considerably more likely to apply for finance. Firms with qualified owners are also more likely to apply for finance, a finding which reflects a large literature on this topic, and the fact that qualified owners are more likely to help achieve firm growth (Barringer et al, 2005). Multiple directors may be a proxy for more systematic top management teams. Larger firms are also more likely to apply for finance, although age does not appear alter matters.

Columns two and three consider whether applications are successful. We find limited evidence that HGFs are more likely to find it difficult to access finance - the coefficient is statistically significant but only at the $10 \%$ level. In terms of absolute credit rationing, despite their increased likelihood of applying, HGFs are no more or less likely than other firms to find they are unable to access finance altogether.

\footnotetext{
12 Note that we also run some tests for multicollinearity. These show no significant problems (e.g. the mean variance inflation factors run between $2.23-3.1$, far below the accepted level of 7 for a problem).
} 
Other factors are also important in determining success of applications for finance. It is clear that the credit crunch worsened conditions. Controlling for recent growth, firm and owner characteristics, firms in 2010 were over five percent more likely to say they had difficulty obtaining finance than those in $2007 / 8$. Size is also important. Applications made by larger firms are more likely to be successful, perhaps reflecting an increased use of company scale as a risk metric by firms and/or greater levels of collateral (Cowling et al. 2012). And there is some evidence that older firms are less likely to be rejected. Neither ethnicity or gender seems to matter once selection effects are accounted for.

In columns 4 and 5, the models control for selection and the likelihood of firms applying for finance. Note that the first stage selection equation is reported in the appendix - this is essentially the same as the regression for applications presented in column 1 . When controlling for selection effects, HGFs actually appear to find it no easier or harder to access finance. These results are presented graphically in Figure 1 which shows the magnitude of the main effects we are interested in, with confidence intervals. Overall, these results run counter to Hypothesis 2: that high growth SMEs find it more difficult to obtain external finance than other firms. Contrary to expectations, there is no penalty detected for rapid firm growth when applying for finance.

Insert figure 1 around here

As with the simple regression models, even controlling for a changed probability of applying for finance, it was harder for firms to obtain finance after the recession. Size is particularly important though, and larger firms are more likely to obtain finance. Controlling 
for their size, firms operating from multiple sites are also less likely to find it easier to access finance.

\section{Discussion}

The empirical findings reported contribute to the growing literatures on access to finance and high growth SMEs. The work revealed that HGFs are significantly (i.e. 9\%) more likely to apply for finance than other SMEs. This corroborates previous research showing external finance to be a fundamental part of the growth process for rapidly growing firms (Vos et al, 2007; Vanacker and Manigart, 2010). Again resonating with other recent research examining HGFs, an interesting finding was the prevalence of debt financing within high growth SMEs (Vanacker and Manigart, 2010). This emphasis on non-equity dilutive sources of funding within HGFs is consistent with the 'pecking order hypothesis' (Myers and Majluf, 1984) and may hinge on the strong desire by entrepreneurs to retain full control of their respective business. However, this seems to contrast sharply with the strong belief by policy makers that equity finance is crucial for HGFs (Brown et al, 2017).

A less expected finding was that high-growth SMEs do not encounter greater problems accessing finance than typical SMEs. Therefore, in spite of being innovative and riskier firms and more likely to apply for finance they are no more likely to encounter problems obtaining finance. This suggests that following the GFC banks did not discriminate against high growth SMEs by denying them credit. However, some other recent research suggests that rapidly growing smaller firms may be penalised by higher borrowing costs (Rostamkalaei and Freel, 2016) which may partly explain their parity with non-HGFs in terms of being able to obtain finance. Cash generative HGFs are presumably more able to service debt less rapidly growing firms cannot which may also explain the willingness of banks to lend to these firms, albeit on less preferable terms. Even during the depths of the recent 
recessionary period covered by the data, our results are consistent with pre-GFC research showing that there is no discernible 'funding gap' for growth-oriented firms (Binks and Ennew, 1996; Vos et al, 2007).

The results also augment our knowledge of 'how' high-growth SMEs grow. Previous work on HGFs has mostly examined 'how much' firms grow rather than 'how' growth occurs (McKelvie and Wiklund, 2010). By examining the reasons for accessing funding, it revealed clear differences between high and low growth SMEs. HGFs are much less likely to seek finance for working capital purposes. The research also found support demonstrating the greater propensity for HGFs to seek finance for riskier strategic investments such as acquisitions. Surprisingly, investment in R\&D seemed of equal importance to high and low growth SMEs. This infers that the construction of "innovativeness" within these firms hinges on more than R\&D expenditure within rapidly growing SMEs (Mason and Brown, 2013).

The findings clearly have implications for public policy. Some authors have noted that while a consensus exists that HGFs are an important stimulus of economic growth, these positive attributes alone do not provide a rationale for policy intervention (Nightingale and Coad, 2014). Indeed, the findings suggest little justification for government intervention aimed at increasing credit availability for HGFs as currently espoused by the UK government. If anything, the findings provide further grounds to question the primacy of HGFs within policy frameworks (Satterthwaite and Hamilton, 2017).

\section{Conclusion}

While HGFs are crucial drivers of innovation and economic growth there has been a dearth of research examining their funding requirements. To address this gap, this paper empirically examined the financial affairs of 8,830 SMEs interviewed as part of the UK's Small Business Survey. This novel research unearthed some key insights which contribute to 
the growing literature on access to finance in SMEs and high growth. Importantly, the findings also challenge the perceptions of HGFs within the policy sphere.

In line with the pecking order thesis, high growth SMEs predominantly rely on traditional sources of debt-based finance not equity finance. The work therefore challenges the overwhelming policy emphasis advocated by some (Duruflé et al, 2017) on developing equity funding as a means of promoting high growth ventures. Despite their strong appetite for external finance, our results strongly suggest they find it no harder than other firms to access external finance, refuting the "strapped for cash" thesis embedded in UK policy frameworks. A key inference is that policy makers may be better served improving credit availability in smaller firms with growth "potential" rather than supporting those already undertaking rapid growth.

As ever, this work has limitations further research could help remedy. While our cross-sectional data provides insights into firm behaviour at certain periods in time, a useful extension would be to use longitudinal data to better control for firm performance and the dynamic relationships between funding and growth. To date, past work on credit constraints in high growth SMEs has predominantly (but not exclusively) been UK focused, so work on these issues in other spatial contexts clearly merits closer attention. Given their central role as drivers of economic growth, we hope this paper stimulates further research examining the capital structure and financial requirements of HGFs.

\section{References}

Anyadike-Danes, M., Bonner, K., Hart, M., \& Mason, C. 2009. Measuring Business Growth: High-growth firms and their contribution to employment in the UK. NESTA, London.

Barringer, B. R., Jones, F. F., \& Neubaum, D. O. 2005. A quantitative content analysis of the characteristics of rapid-growth firms and their founders. Journal of Business Venturing, 20(5), 663-687. 
Berg, T., Burg, V., Gombović, A., \& Puri, M. (2018). On the Rise of FinTechs-Credit Scoring using Digital Footprints (No. w24551). National Bureau of Economic Research.

Berger, A. N., \& Udell, G. F. 1998. The economics of small business finance: The roles of private equity and debt markets in the financial growth cycle. Journal of Banking \& Finance, 22(6), 613-673.

Berger, A. N. and Black, L.K. forthcoming. Small Business Lending: The Roles of Technology and Regulation from Pre-Crisis to Crisis to Recovery, in Berger, A.N., Molyneux, P. and Wilson, J.O.S. (eds.) Oxford Handbook of Banking, $3^{\text {rd }}$ Edition. Oxford: Oxford University Press.

Binks, M. R., \& Ennew, C. T. 1996. Growing firms and the credit constraint. Small Business Economics, 8(1), 17-25.

Birch, D. 1981. Who creates jobs, Public Interest, 65, 3-14.

British Business Bank. 2016. Small Business Finance Markets, British Business Bank, Sheffield.

Brown, R., Mawson, S., \& Mason, C. 2017. Myth-busting and entrepreneurship policy: the case of high growth firms. Entrepreneurship \& Regional Development, 29(5-6), 414-443.

Cassar, G. (2004). The financing of business start-ups. Journal of Business Venturing, 19(2), 261-283.

Comeig, I., Fernández-Blanco, M. O., \& Ramírez, F. 2015. Information acquisition in SME's relationship lending and the cost of loans. Journal of Business Research, 68(7), 1650-1652.

Cowling, M., Liu, W., \& Ledger, a. 2012. Small business financing in the UK before and during the current financial crisis. International Small Business Journal, 30(7), 778-800.

Cressy, R. 2002. Introduction: Funding gaps: A symposium. Economic Journal, F1-F16.

Daunfeldt, S. O., Johansson, D., \& Halvarsson, D. (2015). Using the Eurostat-OECD definition of high-growth firms: a cautionary note. Journal of Entrepreneurship and Public Policy, 4(1), 50-56.

Demir, R., Wennberg, K., \& McKelvie, A. 2017. The strategic management of high-growth firms: a review and theoretical conceptualization. Long Range Planning, 50(4), 431-456.

Dobbs, M., \& Hamilton, R. T. 2007. Small business growth: recent evidence and new directions. International Journal of Entrepreneurial Behavior \& Research, 13(5), 296-322.

Duruflé, G., Hellmann, T. F., \& Wilson, K. E. (2017). From start-up to scale-up: examining public policies for the financing of high-growth ventures, Said Business School RP 2017-05. 
Frame, W. S., Wall, L. D., White, L. J., 2018. Technological Change and Financial Innovation in Banking: Some Implications for Fintech (No. 2018-11). Federal Reserve Bank of Atlanta.

Fraser, S. 2009. Is there Ethnic Discrimination in the UK Market for Small Business Credit? International Small Business Journal, 27(5), 583-607.

Ivashina, V., \& Scharfstein, D. (2010). Bank lending during the financial crisis of 2008. Journal of Financial economics, 97(3), 319-338.

Hambrick, D. C., \& Crozier, L. M. (1985). Stumblers and stars in the management of rapid growth. Journal of Business Venturing, 1(1), 31-45.

Henrekson, M., \& Johansson, D. 2010. Gazelles as job creators: a survey and interpretation of the evidence. Small Business Economics, 35(2), 227-244.

Lee, N. 2014. What holds back high-growth firms? Evidence from UK SMEs. Small Business Economics, 43, 183-195.

Lee, N., Sameen, H, \& Cowling, M. (2015). Access to finance for innovative SMEs since the financial crisis. Research Policy, 44(2), 370-380.

Lee, N., \& Brown, R. (2017). Innovation, SMEs and the liability of distance: the demand and supply of bank funding in UK peripheral regions. Journal of Economic Geography, 17(1), 233260.

Mason, C., \& Brown, R. 2013. Creating good public policy to support high-growth firms. Small Business Economics, 40(2), 211-225.

McKelvie, A., \& Wiklund, J. 2010. Advancing firm growth research: A focus on growth mode instead of growth rate. Entrepreneurship Theory and Practice, 34(2), 261-288.

McKenzie, D. (2017). Identifying and spurring high-growth entrepreneurship: Experimental evidence from a business plan competition. American Economic Review, 107(8), 2278-2307.

Michaelas, N., Chittenden, F., \& Poutziouris, P. (1999). Financial policy and capital structure choice in UK SMEs: Empirical evidence from company panel data. Small Business Economics, $12(2), 113-130$.

Mina, A., Lahr, H., \& Hughes, A. 2013. The Demand and Supply of External Finance for Innovative Firms. Industrial and Corporate Change, 22(4), 869-901.

Myers, S. C., \& Majluf, N. S. 1984. Corporate financing and investment decisions when firms have information that investors do not have. Journal of Financial Economics, 13(2), 187-221.

Nightingale, P., \& Coad, A. 2014. Muppets and gazelles: political and methodological biases in entrepreneurship research. Industrial and Corporate Change, 23, 113-143. 
Petersen, M. A., \& Rajan, R. G. (1994). The benefits of lending relationships: Evidence from small business data. The journal of Finance, 49(1), 3-37.

Rostamkalaei, A., \& Freel, M. 2016. The cost of growth: small firms and the pricing of bank loans. Small Business Economics, 46(2), 255-272.

Satterthwaite, S., \& Hamilton, R. T. (2017). High-growth firms in New Zealand: Superstars or shooting stars?. International Small Business Journal, 35(3), 244-261.

Segarra, A., \& Teruel, M. 2014. High-growth firms and innovation: an empirical analysis for Spanish firms. Small Business Economics, 43, 805-821.

Shane, S. 2010. Why encouraging more people to become entrepreneurs is bad public policy, Small Business Economics, 33(2), 141-149.

Stiglitz, J. E., \& Weiss, A. 1981. Credit rationing in markets with imperfect information. The American Economic Review, 71(3), 393-410.

Storey, D. Watson, R. \& Wynarczyk, P. 1987. Fast Growth Small Businesses: Case Studies of 40 Small firms in Northern England, Department of Employment, Research Paper No 67.

Rostamkalaei, A. and Freel, M., 2017. Business advice and lending in small firms. Environment and Planning C: Politics and Space, 35(3), pp.537-555.

Udell, G. F. (2015). Issues in SME access to finance. European Economy, 1 (2), 61-74.

Vanacker, T. \& Manigart, S. 2010. Pecking order and debt capacity considerations for high growth companies seeking finance, Small Business Economics, 35, 53-69.

Vos, E., Yeh, A. J. Y., Carter, S., \& Tagg, S. 2007. The happy story of small business financing. Journal of Banking \& Finance, 31(9), 2648-2672.

Welter, F., Baker, T., Audretsch, D. B., \& Gartner, W. B. (2017). Everyday entrepreneurshipa call for entrepreneurship research to embrace entrepreneurial diversity. Entrepreneurship Theory and Practice, 41(3), 311-321.

Westhead, P., \& Storey, D. J. (1997). Financial constraints on the growth of high technology small firms in the United Kingdom. Applied Financial Economics, 7(2), 197-201.

Wright, M., Roper, S., Hart, M., \& Carter, S. (2015). Joining the dots: Building the evidence base for SME growth policy. International Small Business Journal, 33(1), 3-11.

Table 1. Empirical Studies Comparing Credit Constraints in HGFs relative to non-HGFs 


\begin{tabular}{|l|l|l|}
\hline Authors & $\begin{array}{l}\text { Higher Credit Constraints in HGFs } \\
\text { than non-HGFs }\end{array}$ & $\begin{array}{l}\text { Credit Constraints Similar to non- } \\
\text { HGFs }\end{array}$ \\
\hline Hambrick \& Crozier (1986) & Yes & \\
\hline Storey et al (1989) & Yes & \\
\hline Binks \& Ennew (1996) & & Yes \\
\hline Westhead \& Storey (1997) & Yes & \\
\hline Vos et al (2007) & & Yes \\
\hline Lee (2014) & Yes & \\
\hline
\end{tabular}

Table 2. The sample: High growth firms by year

\begin{tabular}{|l|l|l|l|l|l|}
\hline & & $2007 / 8$ & 2010 & 2012 & Total \\
\hline Non-high growth & $\%$ & 94.6 & 96.4 & 95.5 & 95.3 \\
\cline { 2 - 6 } & Number & 3,806 & 2,052 & 2,477 & 8,335 \\
\hline High growth & $\%$ & 5.4 & 3.6 & 4.5 & 4.7 \\
\cline { 2 - 6 } & Number & 254 & 93 & 148 & 495 \\
\hline Total & $\%$ & 100 & 100 & 100 & 100 \\
\cline { 2 - 6 } & & & & & 8,830 \\
\cline { 2 - 6 } & Number & 4,060 & 2,145 & 2,625 & \\
\hline
\end{tabular}

Source: Small Business Survey, 2007/8, 2010; 2012. Notes: Percentages weighted to ensure they are representative of SMEs. Number of firms unweighted.

Table 3. Applications for finance and reported difficulties

\begin{tabular}{|l|l|l|l|}
\hline \multirow{2}{*}{ finance } & \multicolumn{2}{|l|}{ Percentage of firms which } \\
\cline { 3 - 4 } & Applied for external & Of those who applied: \\
\cline { 3 - 4 } & & Had trouble obtaining & Did not get any finance \\
& finance from first source & from any source \\
\hline
\end{tabular}




\begin{tabular}{|l|l|l|l|}
\hline Non-HGF & 32.82 & 34.22 & 15.81 \\
\hline HGF & 43.68 & 31.65 & 13.29 \\
\hline Overall & & & \\
& 33.33 & 34.06 & 15.66 \\
\hline P-value & & & \\
& 0.000 & 0.537 & 0.405 \\
\hline
\end{tabular}

Sample: 8830, 3051 of whom applied for finance. Source: Small Business Survey, 2007/8, 2010; 2012. Weights applied.

Table 4. External and internal sources of finance

Do you expect to fund your business growth using internal finances or from external sources?

\begin{tabular}{|l|l|l|l|}
\hline Source of finance & Not high growth & High growth firm & Total \\
\hline Percentage of firms & & & \\
\hline Internal finance & 61.4 & 50.7 & 60.7 \\
\hline External finance & 15.2 & 14.9 & 15.2 \\
\hline Both & 23.5 & 34.4 & 24.1 \\
\hline Percentage of all firms: & & & 11.4 \\
\hline Internal finance & 11.3 & 13.6 & \\
\hline Both & & & 12.0 \\
\hline
\end{tabular}




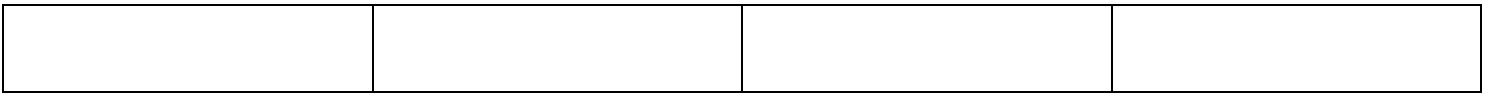

Source: Small Business Survey, 2007/8 and 2010. Sample: 4,860 firms from 2007/8 and 2010 surveys - all of which aim to grow. Weights applied. Percentages may not total to 100 due to rounding.

Table 5. Reasons for applications and type of finance sought

\begin{tabular}{|c|c|c|c|c|c|}
\hline & & High growth & Other firms & Total & P-value \\
\hline \multirow{6}{*}{$\begin{array}{l}\text { Reason for } \\
\text { applying for } \\
\text { finance (\% of } \\
\text { firms that } \\
\text { applied) }\end{array}$} & $\begin{array}{l}\text { Working } \\
\text { capital }\end{array}$ & 35.7 & 47.2 & 46.5 & 0.007 \\
\hline & $\begin{array}{l}\text { Buying or } \\
\text { improving } \\
\text { buildings }\end{array}$ & 18.9 & 18.5 & 18.5 & 0.905 \\
\hline & $\begin{array}{l}\text { Acquiring } \\
\text { capital } \\
\text { equipment } \\
\text { or vehicles }\end{array}$ & 25.8 & 26.4 & 26.3 & 0.881 \\
\hline & $\begin{array}{l}\text { Research } \\
\text { and } \\
\text { development }\end{array}$ & 3.8 & 3.4 & 3.4 & 0.761 \\
\hline & $\begin{array}{l}\text { Buying } \\
\text { another } \\
\text { business }\end{array}$ & 6.6 & 1.6 & 1.9 & 0 \\
\hline & $\begin{array}{l}\text { To fund } \\
\text { expansion }\end{array}$ & 8.8 & 3.3 & 3.6 & 0.003 \\
\hline \multirow{7}{*}{$\begin{array}{r}\text { What type of } \\
\text { finance did } \\
\text { you seek? (\% } \\
\text { of firms that } \\
\text { applied): }\end{array}$} & Bank loan & 48.6 & 39 & 39.6 & 0.025 \\
\hline & $\begin{array}{l}\text { Bank } \\
\text { overdraft }\end{array}$ & 18.4 & 26.8 & 26.3 & 0.02 \\
\hline & $\begin{array}{l}\text { Venture } \\
\text { capital }\end{array}$ & 4.8 & 1 & 1.2 & 0.001 \\
\hline & Grant & 5.9 & 8.1 & 8 & 0.238 \\
\hline & $\begin{array}{l}\text { Leasing / } \\
\text { hire } \\
\text { purchase }\end{array}$ & 12.5 & 12.9 & 12.9 & 0.868 \\
\hline & $\begin{array}{l}\text { Loan from } \\
\text { family / } \\
\text { directors }\end{array}$ & 2.2 & 2.1 & 2.1 & 0.945 \\
\hline & Mortgage & 5.7 & 5.8 & 5.8 & 0.943 \\
\hline
\end{tabular}

Source: Small Business Survey, 2007/8, 2010 and 2012. Sample: 3,152 firms - all of whom apply for finance, of which 230 were high growth Weights applied 
Table 6. Probit model: High growth firms and difficulty accessing finance
(1)
(2)
(3)
(4)
(5)

\begin{tabular}{|c|c|c|c|c|c|}
\hline Estimation & Probit & & & Probit with hec & nan selection \\
\hline $\begin{array}{l}\text { Dependent } \\
\text { variable: }\end{array}$ & $\begin{array}{l}\text { Firm applied for } \\
\text { finance }\end{array}$ & $\begin{array}{l}\text { Firm applied and } \\
\text { had difficulty } \\
\text { obtaining from } \\
\text { first source }\end{array}$ & $\begin{array}{l}\text { Firm obtained } \\
\text { nothing from any } \\
\text { source }\end{array}$ & $\begin{array}{l}\text { Firm applied } \\
\text { and had } \\
\text { difficulty } \\
\text { obtaining from } \\
\text { first source }\end{array}$ & $\begin{array}{l}\text { Firm obtained } \\
\text { nothing from } \\
\text { any source }\end{array}$ \\
\hline $\begin{array}{l}\text { High growth } \\
\text { firm }\end{array}$ & $\begin{array}{l}0.0744^{* *} \\
(0.0293)\end{array}$ & $\begin{array}{l}0.0340 * \\
(0.0207)\end{array}$ & $\begin{array}{l}0.00526 \\
(0.0116)\end{array}$ & $\begin{array}{l}0.0396 \\
(0.382)\end{array}$ & $\begin{array}{l}0.0135 \\
(2.998)\end{array}$ \\
\hline Year: 2010 & $\begin{array}{l}-0.00717 \\
(0.0206)\end{array}$ & $\begin{array}{l}0.0562^{* * *} \\
(0.0155)\end{array}$ & $\begin{array}{l}0.0183^{*} \\
(0.00980)\end{array}$ & $\begin{array}{l}0.165 \\
(1.407)\end{array}$ & $\begin{array}{l}0.0326 \\
(7.092)\end{array}$ \\
\hline Year: 2012 & $\begin{array}{l}-0.0539 * * * \\
(0.0189)\end{array}$ & $\begin{array}{l}0.0114 \\
(0.0137)\end{array}$ & $\begin{array}{l}0.00526 \\
(0.00927)\end{array}$ & $\begin{array}{l}0.131 \\
(1.187)\end{array}$ & $\begin{array}{l}0.0165 \\
(3.710)\end{array}$ \\
\hline Size: $100+$ & $\begin{array}{l}0.0156 \\
(0.0338)\end{array}$ & $\begin{array}{l}-0.0525^{* *} \\
(0.0232)\end{array}$ & $\begin{array}{l}-0.0154 \\
(0.0141)\end{array}$ & $\begin{array}{l}-0.139 \\
(1.296)\end{array}$ & $\begin{array}{l}-0.0302 \\
(6.722)\end{array}$ \\
\hline Size: 50 - 99 & $\begin{array}{l}0.0764^{* *} \\
(0.0371)\end{array}$ & $\begin{array}{l}-0.0519 * * * \\
(0.0154)\end{array}$ & $\begin{array}{l}-0.0237^{* *} \\
(0.00979)\end{array}$ & $\begin{array}{l}-0.153 \\
(1.730)\end{array}$ & $\begin{array}{l}-0.0366 \\
(8.683)\end{array}$ \\
\hline Female led & $\begin{array}{l}-0.0353 \\
(0.0248)\end{array}$ & $\begin{array}{l}0.00839 \\
(0.0183)\end{array}$ & $\begin{array}{l}-0.00182 \\
(0.00969)\end{array}$ & $\begin{array}{l}0.00474 \\
(0.0567)\end{array}$ & $\begin{array}{l}-0.00198 \\
(0.458)\end{array}$ \\
\hline Ethnic led & $\begin{array}{l}0.0132 \\
(0.0378)\end{array}$ & $\begin{array}{l}0.0351 \\
(0.0281)\end{array}$ & $\begin{array}{l}0.0220 \\
(0.0203)\end{array}$ & $\begin{array}{l}0.0681 \\
(0.622)\end{array}$ & $\begin{array}{l}0.00856 \\
(1.924)\end{array}$ \\
\hline $\begin{array}{l}\text { Qualified } \\
\text { owner }\end{array}$ & $\begin{array}{l}0.0274 \\
(0.0189)\end{array}$ & $\begin{array}{l}0.0175 \\
(0.0120)\end{array}$ & $\begin{array}{l}0.0103 \\
(0.00710)\end{array}$ & $\begin{array}{l}-0.00298 \\
(0.0361)\end{array}$ & $\begin{array}{l}0.00244 \\
(0.564)\end{array}$ \\
\hline $\begin{array}{l}\text { Multiple } \\
\text { directors }\end{array}$ & 0.00310 & $\begin{array}{l}0.00143 \\
(0.00154)\end{array}$ & $\begin{array}{l}0.000785 \\
(0.000864)\end{array}$ & $\begin{array}{l}0.00116 \\
(0.0121)\end{array}$ & $\begin{array}{l}0.000182 \\
(0.0419)\end{array}$ \\
\hline Aims to grow & $0.0644^{* * *}$ & $0.0240 *$ & $0.0169 * *$ & 0.0198 & 0.0113 \\
\hline
\end{tabular}




\begin{tabular}{|c|c|c|c|c|c|}
\hline & $(0.0203)$ & (0.0129) & $(0.00738)$ & $(0.211)$ & (2.662) \\
\hline \multirow[t]{2}{*}{ Takes advice } & $0.107 * * *$ & $0.0528^{* * *}$ & $0.0173^{* *}$ & 0.0660 & 0.0169 \\
\hline & $(0.0166)$ & $(0.0114)$ & $(0.00718)$ & (0.679) & (3.882) \\
\hline \multirow[t]{2}{*}{ Age: $10+$} & -0.0574 & -0.0231 & -0.0161 & -0.0455 & -0.00807 \\
\hline & $(0.0430)$ & (0.0223) & (0.0109) & (0.517) & (1.907) \\
\hline \multirow[t]{2}{*}{ Age: 5 - 9} & $-0.0527^{* *}$ & $-0.0401 * *$ & $-0.0260 * * *$ & -0.0643 & -0.0226 \\
\hline & $(0.0240)$ & $(0.0168)$ & $(0.00996)$ & (0.609) & (4.959) \\
\hline \multirow{2}{*}{ Constant } & 0.0182 & -0.0128 & 0.00679 & -0.0474 & 0.0230 \\
\hline & $(0.0463)$ & $(0.0354)$ & $(0.0165)$ & $(0.0665)$ & $(0.0686)$ \\
\hline Sector & Yes & Yes & Yes & Yes & Yes \\
\hline dummies & & & & & \\
\hline Observations & 8,190 & 8,080 & 8,120 & 8,072 & 8,110 \\
\hline Pseudo $\mathrm{R}^{2}$ & 0.0281 & 0.0568 & 0.0504 & & \\
\hline LR Test & & & & 5.27 & 0.33 \\
\hline P-value & & & & 0.0217 & 0.5684 \\
\hline Log-likelihood & & & & -690.6281 & -631.9703 \\
\hline
\end{tabular}

Source: Small Business Survey, 2007/8, 2010 and 2012. Marginal effects presented. Robust standard errors in parenthesis. ${ }^{* * *} p<0.01 ; * * p<0.05 ;{ }^{*} p<0.1$. All models also include 16 sector dummies. Where sample sizes vary this is because the dependent variable is perfectly predicted by independent variables. Regressions $1-3$ are estimated as probit regressions. Regressions 4 and 5 are probit regressions with Heckman correction. The selection variable is legal status.

Figure 1. Coefficient plot: High-growth firm financing models 


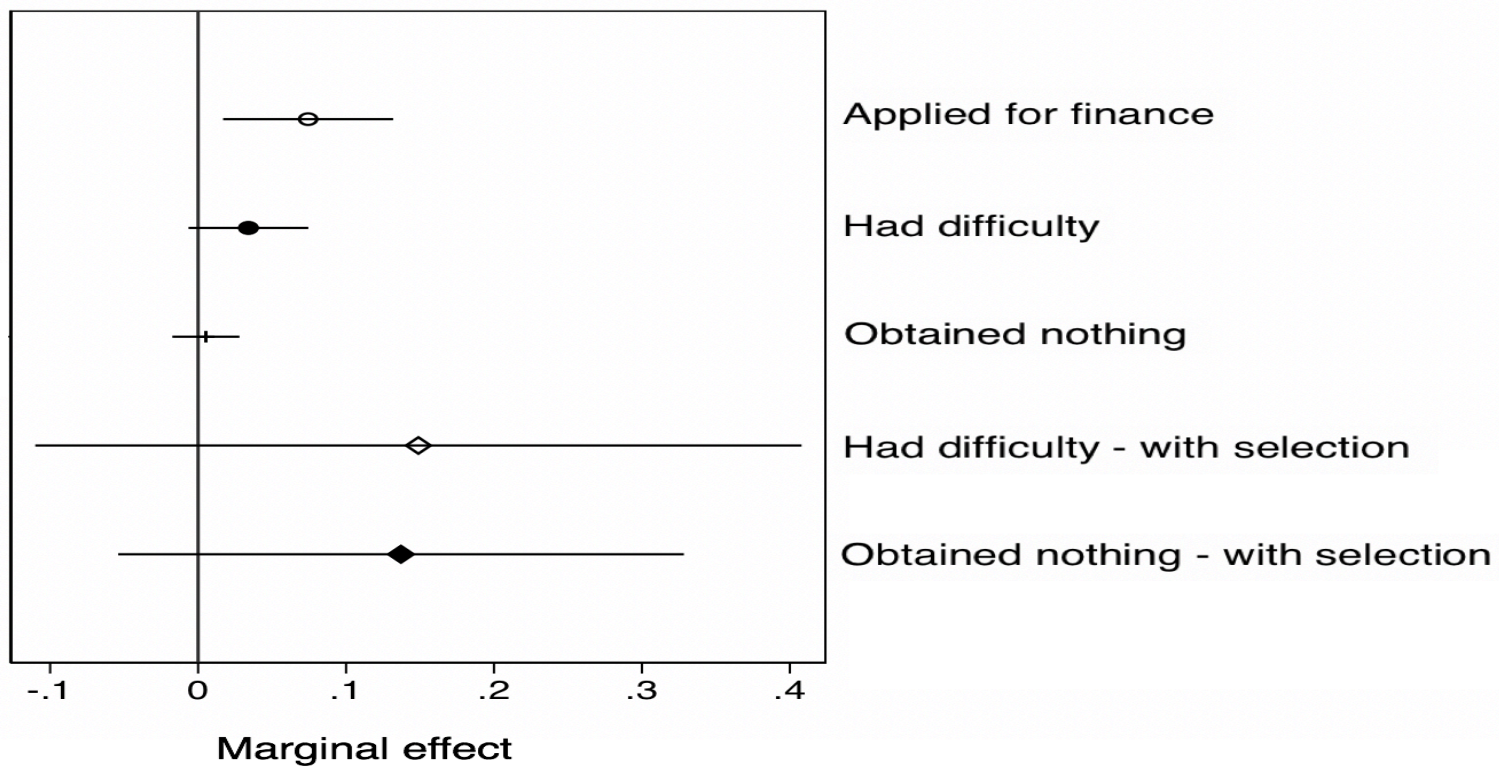

Note: Figure gives the coefficient plots for regressions $1-5$ in table 6 . Markers indicate point estimates, bars give confidence intervals.

Appendix: First stage regressions

\begin{tabular}{|c|c|c|c|c|}
\hline & (1) & & (2) & \\
\hline Model & $\begin{array}{l}\text { Firm applied } \\
\text { and had } \\
\text { difficulty } \\
\text { obtaining } \\
\text { from first } \\
\text { source }\end{array}$ & $\begin{array}{l}\text { First stage: } \\
\text { Firm applied } \\
\text { for finance }\end{array}$ & $\begin{array}{l}\text { Firm } \\
\text { obtained } \\
\text { nothing from }\end{array}$ & $\begin{array}{l}\text { First stage: } \\
\text { Firm applied } \\
\text { for finance }\end{array}$ \\
\hline \multirow[t]{2}{*}{ High growth firm } & 0.149 & $0.230 * * *$ & 0.137 & $0.223^{* * *}$ \\
\hline & $(0.132)$ & $(0.0627)$ & $(0.0975)$ & $(0.0624)$ \\
\hline \multirow[t]{2}{*}{ Year $=2010$} & $0.579 * * *$ & -0.0364 & $0.318^{* * *}$ & -0.0530 \\
\hline & $(0.149)$ & $(0.0380)$ & $(0.0602)$ & (0.0379) \\
\hline \multirow[t]{2}{*}{ Year $=2012$} & $0.476 * * *$ & $-0.121 * * *$ & $0.174 * * *$ & $-0.110 * * *$ \\
\hline & $(0.172)$ & $(0.0370)$ & $(0.0606)$ & $(0.0366)$ \\
\hline \multirow[t]{2}{*}{ Size: $100+$} & $-0.518 * * *$ & -0.0882 & $-0.312 * * *$ & -0.0690 \\
\hline & $(0.146)$ & $(0.0817)$ & $(0.112)$ & $(0.0818)$ \\
\hline
\end{tabular}




\begin{tabular}{|c|c|c|c|c|}
\hline Size: 50 - 99 & $-0.696 * * *$ & 0.0397 & $-0.471 * * *$ & 0.0570 \\
\hline & $(0.221)$ & $(0.0844)$ & $(0.120)$ & $(0.0846)$ \\
\hline \multirow[t]{2}{*}{ Female led } & 0.0188 & $-0.0984 * *$ & -0.0227 & $-0.0897^{*}$ \\
\hline & $(0.107)$ & (0.0491) & (0.0757) & (0.0487) \\
\hline \multirow[t]{2}{*}{ Ethnic led } & $0.246 * *$ & 0.0204 & 0.0899 & 0.0436 \\
\hline & $(0.121)$ & (0.0701) & (0.105) & $(0.0693)$ \\
\hline \multirow[t]{2}{*}{ Qualified owner } & -0.0119 & 0.0446 & 0.0279 & 0.0491 \\
\hline & (0.0719) & $(0.0373)$ & (0.0638) & $(0.0372)$ \\
\hline \multirow[t]{2}{*}{ Multiple directors } & 0.00462 & $0.0123 * *$ & 0.00205 & $0.0104 * *$ \\
\hline & $(0.00995)$ & $(0.00533)$ & $(0.00881)$ & (0.00528) \\
\hline \multirow[t]{2}{*}{ Aims to grow } & 0.0810 & $0.216 * * *$ & $0.137^{* *}$ & $0.226 * * *$ \\
\hline & $(0.127)$ & $(0.0384)$ & $(0.0660)$ & $(0.0382)$ \\
\hline \multirow[t]{2}{*}{ Takes advice } & $0.264^{* * *}$ & $0.237^{* * *}$ & $0.190 * * *$ & $0.229 * * *$ \\
\hline & $(0.0948)$ & $(0.0307)$ & (0.0511) & (0.0305) \\
\hline \multirow[t]{2}{*}{ Age: 10 + } & -0.200 & 0.00957 & -0.0985 & 0.0212 \\
\hline & $(0.146)$ & $(0.0853)$ & $(0.127)$ & $(0.0848)$ \\
\hline \multirow[t]{2}{*}{ Age: 5 - 9} & $-0.239 * * *$ & $-0.0872 * *$ & $-0.224 * * *$ & $-0.0787^{*}$ \\
\hline & $(0.0696)$ & $(0.0429)$ & $(0.0638)$ & $(0.0427)$ \\
\hline \multirow[t]{2}{*}{ Legal structure: } & & $0.248 * *$ & & $0.254 * * *$ \\
\hline & & (0.0991) & & $(0.0905)$ \\
\hline \multirow[t]{2}{*}{ Legal structure: } & & 0.113 & & 0.0976 \\
\hline & & $(0.0923)$ & & (0.0729) \\
\hline \multirow[t]{2}{*}{ Constant } & -0.600 & $-0.784 * * *$ & $-1.477 * * *$ & $-0.794 * * *$ \\
\hline & $(0.945)$ & $(0.145)$ & $(0.172)$ & $(0.131)$ \\
\hline Observations & 8,072 & 8,072 & 8,110 & 8,110 \\
\hline
\end{tabular}


Source: Small Business Survey, 2007/8, 2010 and 2012. Untransformed probit coefficients presented. Robust standard errors in parenthesis. ${ }^{* *} p<0.01 ;{ }^{* *} p<0.05 ;{ }^{*} p<0.1$. All models also include 16 sector dummies. 